\title{
The Political Segregation of the United States
}

\begin{abstract}
By L. Jan Reid
The federal bicameral legislature of the United States of America (U.S.) is currently dysfunctional, in that it is unable to pass legislation to address important issues such as immigration reform and economic development. I show that dysfunctional government in the U.S. is largely a byproduct of "political segregation": a phenomenon in which liberals tend to relocate to live in areas where liberal voters are in the majority, and conservatives tend to relocate to live in areas where conservative voters are in the majority. I analyze U.S. presidential election data by state from 1976-2012, and show that a shift occurred in voting behavior for key American states after 1976. I explore some of the reasons for these political trends and I review and discuss the psychological literature related to voting behavior.
\end{abstract}

Keywords: Immigration, Migration, Political dysfunction, Political segregation, U.S. presidential elections.

\section{Introduction}

There are two major political parties in the United States, the Democratic Party and the Republican Party. ${ }^{1}$ The modern Democratic Party was formed in 1828 and the modern Republican Party was formed in $1856 .^{2}$ No other party has won the presidency since the Whigs won in 1848.

In the 1976 election, Democrat Jimmy Carter was elected President of the United States. Since the 1976 election, there has been a significant change in the voting patterns of the most liberal and the most conservative states. Although California is now one of America's most liberal states and Mississippi is now one of America's most conservative states, in 1976, those states' voting patterns were similar. In 1976, California voted $1.97 \%$ less Democratic than the nation as a whole, and Mississippi voted $0.09 \%$ less Democratic. In the election of 2012, California voted $9.91 \%$ more Democratic, and Mississippi voted $7.76 \%$ less Democratic. In the average election from 1980-2012, California voted 4.13\% more Democratic and Mississippi voted $6.29 \%$ less Democratic.

These changes in voting behavior are driven by population movement and by immigration. Liberals have tended to move to liberal states and conservatives have tended to move to conservative states. This population migration is even more pronounced inside congressional districts within certain states.

\footnotetext{
* Coast Economic Consulting, USA.

${ }^{1}$ The Republican Party is also known as the GOP (Grand Old Party).

2 The Democratic-Republican Party (DRP) nominated a presidential candidate from 1792 to 1824. Beginning in 1828 the DRP split into two parties, the Democratic Party and the National Republican Party (NRP). The NRP nominated a presidential candidate from 1828 to 1832 . The Whig party was formed in 1836 and nominated a presidential candidate from 1836 to 1852 .
} 
"The Big Sort" by Bill Bishop and Roger Cushing addresses political segregation. I refer to the concepts they present as the Big Sort Theory.

\section{Literature Review} below:

My literature review explored five questions, discussed in the sections

1. How has party polarization affected governmental decisions?

2. Is dysfunctional government a byproduct of political segregation?

3. When did voting trends begin to change?

4. How do groups affect the political views of individuals?

5. Has the traditional role of politicians changed?

How Has Party Polarization Affected Governmental Decision Making in the United States

A number of papers have dealt with the effect of party polarization on governance in the United States. Bowling and Pickerill (2013) found that party polarization at the state and federal level has hindered the adoption of numerous policies.

When parties are polarized, elected officials become highly ideological, thus affecting the political agenda of decision makers (Pickerill and Bowling 2014). Since the mid-1970s, Democrats and Republicans in Congress have moved away from the ideological center and toward their respective liberal and conservative poles (Poole 2012).

Noam Lupu has argued that party polarization may also have beneficial results. In Lupu's view, party polarization may result in electoral stability (Lupu 2015).

A number of solutions have been proposed to reduce party polarization; however, their potential effectiveness is questionable. The most noteworthy proposal, campaign finance reform, was analyzed by Thomas E. Mann and Anthony Carrado, who found that campaign finance reform, is a weak tool for depolarizing American political parties (Mann and Carrado 2014).

\section{Is Dysfunctional Government a Byproduct of Political Segregation?}

Although political segregation is a major contributor to dysfunctional government, it would be simplistic to argue that dysfunctional government is caused solely by political segregation. Group polarization (see section "When Did Voting Trends Begin to Change?") also plays a role in this process. Sunstein (1999: 25) has explained that:

Imagine, for example, that a group of Republicans and a group of Democrats are thinking about how to vote on a proposed law ... If 
Republicans are speaking mostly with Republicans, and if Democrats are speaking mostly with Democrats, we should expect a hardening of views toward the more extreme points.

Ortoleva and Snowberg (2015: 504-505) have theorized that "differences in ideology are also due to imperfect information processing". Their theory predicts that "overconfidence in one's own beliefs leads to ideological extremeness, increased voter turnout, and stronger identification with political parties".

Since compromise is viewed with disfavor by federal politicians (see section "Political Dysfunction"), it is likely that Democrats speak mostly with Democrats and Republicans speak mostly with Republicans. This is part of a process that leads to dysfunctional government. A simple explanation of this process is given below.

1. Political segregation occurs as voters segregate themselves into communities composed of like-minded individuals.

2. Congressional districts become more partisan and representatives are elected based on their ideological views, rather than on their skill as legislators.

3. Once elected, members of Congress primarily talk to members of their own party, thereby accelerating the process of group polarization.

4. The political parties and their constituents develop more extreme views due to the effect of group polarization.

5. Congress becomes more dysfunctional (unable to compromise and pass important legislation) due to political segregation, political polarization, and group polarization.

\section{When Did Voting Trends Begin to Change?}

Bishop and Cushing published an analysis of U.S. county voting patterns in 2008. They defined a "landslide county" as one in which the local presidential election was decided by 20 or more percentage points (Bishop and Cushing 2008: 9). They have explained that:

From 1948 to 1976, the vote jumped around, but in the close elections, Republicans and Democrats became evenly mixed, especially in the 1976 contest. After 1976, the trend was for Republicans and Democrats to become more geographically segregated.

In 1976, 26.8\% of American counties were landslide counties. By 2004, $45.3 \%$ of Americans counties were landslide counties. My own state-level analysis of U.S. presidential elections confirms Bishop and Cushing's analysis: there was a significant shift in voting patterns after 1976. 
Since most U.S. congressional districts include more than one county, noncompetitive counties will result in non-competitive congressional districts. I define a "non-competitive congressional district" as a district in which the winning candidate received more than $55 \%$ of the two-party vote. In the 2012 congressional elections, the Democrats received 50.23\% of the two-party vote. However, only 56 of 435 congressional districts were competitive in $2012 .^{3}$

\section{How do Groups Affect the Political Views of Individuals?}

Three major contemporary social psychological theories focus on why people join and identify with groups: the sociometer model, terror management theory, and uncertainty-identity theory.

Hogg et al. (2008: 1) have explained that:

The sociometer model argues that people have a need to be socially included, and that self-esteem is a meter of successful inclusion and group belonging. Terror management theory argues that people are motivated to reduce fear of the inevitability of their own death, and that the consensual belief-confirmation provided by groups drives people to belong. Uncertainty-identity theory argues that people have a basic need to reduce uncertainty about themselves, their attributes, and their place in the world, and that cognitive processes associated with group identification reduce such uncertainty.

Regardless of which theory one believes, the fact is that Americans join groups. There are hundreds of thousands of public groups in the United States, ranging from Democratic and Republican clubs, to charitable groups, to nonpartisan political-interest groups, to public-service clubs. Almost all of these groups affect the political behavior of their members.

Sunstein (1999: 3-4) has explained that "in brief, group polarization arises when members of a deliberating group move toward a more extreme point in whatever direction is indicated by the members' predeliberation tendency".

Bishop and Cushing (2008: 69) have explained that (from Myers, Social Psychology: 313-316):

When a person learns that members in a group share his or her general beliefs, he or she finds it socially advantageous to adopt a position slightly more extreme than the group average. It's a safe way to stand out from the crowd. It brings notice and even approbation.

Thus, the views of the group and its constituent individuals become more extreme over time. In political terms, liberals living in conservative areas become more conservative, and conservatives living in liberal areas become

${ }^{3}$ Calculated from data obtained from the Cooperative Congressional Election Study (https://dataverse.harvard.edu/dataverse/cces). 
more liberal. My analysis of U.S. voting behavior (see Section "Migration") supports the theory of group polarization.

\section{Has the Traditional Role of Politicians Changed?}

Bishop and Cushing (2008: 296) have explained that:

At one time the politician's profession was to have divided loyalties. ... Politicians such as [Bert] Combs and Lyndon Johnson were specialists in the art of showing just enough to win the turkey. With discretion and sometimes duplicity, they represented diverse and conflicting factions within a county or a state, and through them disputes were mediated. ${ }^{4}$

Population migration has led to a situation in which congressional-district residents have become more extreme, and congressional districts are often dominated by a single political party. The legislators who are elected from these congressional districts have also become more extreme. If a member of Congress is concerned about a primary election in which there might be opposition from the member's own party, the member will cast votes that maximize political support from that party.

\section{Voting Trends}

I collected data from U.S. presidential elections from 1976-2012. I analyzed the data by calculating the difference between a state's Democratic Party percentage of the two-party vote in that state, and comparing it to the nationwide two-party vote. For example, in 1976, Democrats received $49.08 \%$ of the two-party vote in California and $51.05 \%$ of the vote nationwide. Thus, California had a score of $-1.97 \%$ in $1976(49.08 \%-51.05 \%=1.97 \%)$.

I then calculated the average shift over the 1976-2012 election period among the ten regions with the largest percentage shifts in voting results. Results are given in Table 1.

Table 1. Top Ten Regions: Highest Average Change in Democratic Vote Percentage from 1976-2012

\begin{tabular}{|c|c|c|}
\hline Period & Average Change & Top Ten Regions \\
\hline $1976-2012$ & $12.06 \%$ & California, Connecticut, District of \\
& & $\begin{array}{c}\text { Columbia, Hawaii, Illinois, Maryland, New } \\
\text { Jersey, New York, Vermont, and } \\
\text { Washington. }\end{array}$ \\
\hline
\end{tabular}

Source: Cooperative Congressional Election Study (2015).

\footnotetext{
${ }^{4}$ Bert Combs was governor of Kentucky from 1959-1963 and Lyndon Johnson was president of the United States from 1963-1969.
} 
The 1976-2012 election results appear to be strongly affected by migration and legal immigration. I discuss each of these factors below.

\section{Migration}

As mentioned previously, the 1976-2012 elections appear to be strongly affected by political segregation and voter migration. Due to data restrictions, I limited my analysis of voter migration to a more recent time period. From 1992 to 2012, the top ten regions were California, Connecticut, District of Columbia, Delaware, Hawaii, Maryland, New Jersey, New York, Vermont, and Virginia. A map of the United States is given below.

Figure 1. Map of the United States

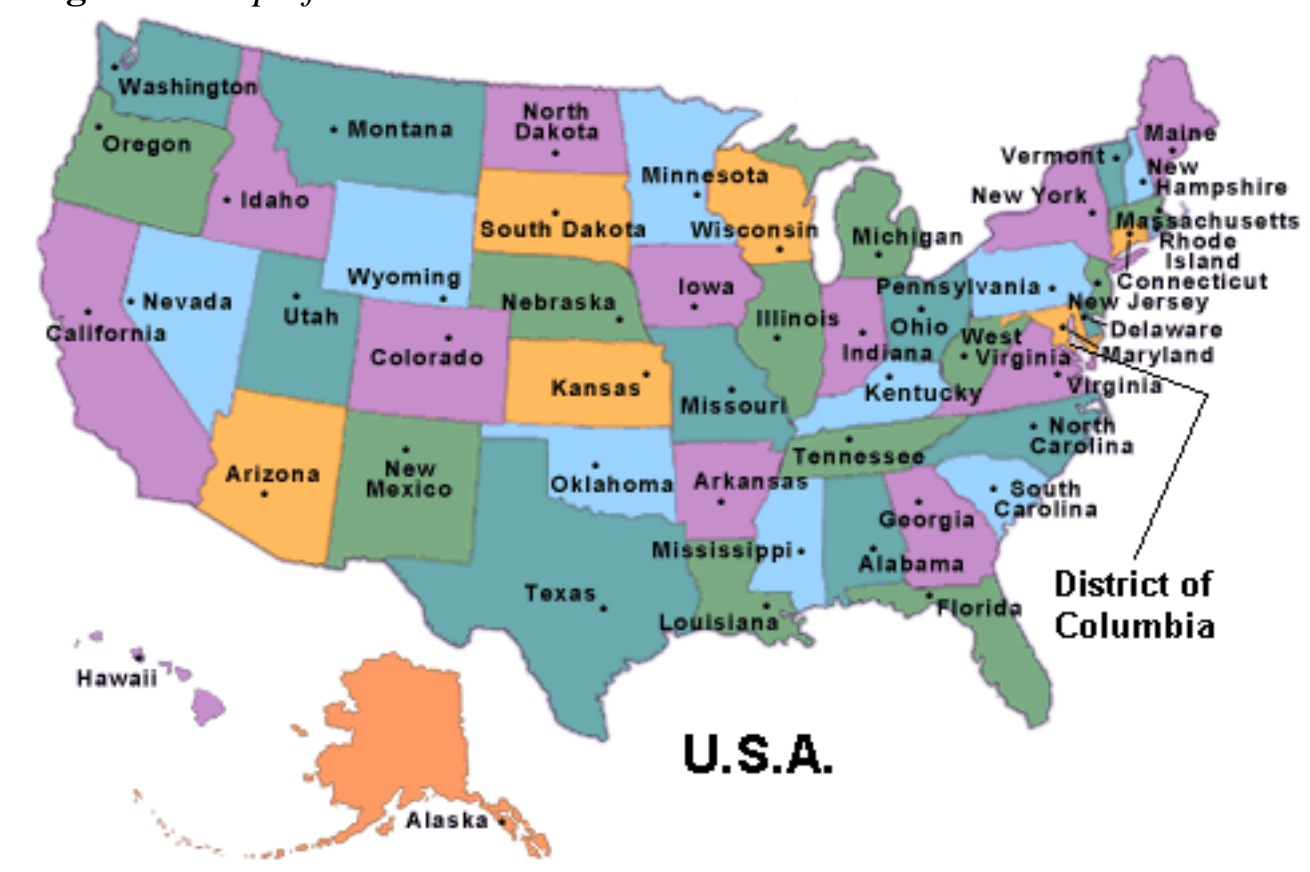

Source: http://bit.ly/1jlgm3v.

In Table 2, I compare the increase in Democratic votes in selected regions to the migration into those regions minus the out-migration from that region to the nine other top-ten regions. The purpose of this analysis is to determine whether the Big Sort Theory discussed above could have resulted in a change in voting behavior from 1992-2012. 
Table 2. Voting Patterns and Migration to Selected Regions from 1992 to 2012

\begin{tabular}{|l|c|c|c|c|c|}
\hline \multicolumn{1}{|c|}{ Region } & $\begin{array}{c}\text { Voter } \\
\text { Turnout }\end{array}$ & $\begin{array}{c}\text { Migrant } \\
\text { In- } \\
\text { Migration }\end{array}$ & $\begin{array}{c}\text { Migrant } \\
\text { Out- } \\
\text { Migration }\end{array}$ & $\begin{array}{c}\text { Estimated } \\
\text { Votes Cast }\end{array}$ & $\begin{array}{c}\text { Increase in } \\
\text { Dem. } \\
\text { Votes }\end{array}$ \\
\hline California & $55.90 \%$ & $3,523,153$ & 585,174 & $1,642,330$ & $2,732,960$ \\
\hline Connecticut & $61.50 \%$ & 590,419 & 247,481 & 210,907 & 281,765 \\
\hline Delaware & $62.00 \%$ & 234,747 & 80,860 & 95,410 & 116,530 \\
\hline $\begin{array}{l}\text { District of } \\
\text { Columbia }\end{array}$ & $63.30 \%$ & 373,630 & 305,391 & 43,195 & 74,451 \\
\hline Hawaii & $44.50 \%$ & 358,134 & 133,336 & 100,035 & 127,348 \\
\hline Maryland & $66.80 \%$ & $1,218,007$ & 535,612 & 455,840 & 689,273 \\
\hline New Jersey & $62.60 \%$ & $1,296,797$ & 606,867 & 431,896 & 686,580 \\
\hline New York & $53.60 \%$ & $2,107,498$ & $1,140,228$ & 518,457 & $1,027.421$ \\
\hline Vermont & $60.90 \%$ & 157,727 & 46,832 & 67,535 & 65,647 \\
\hline Virginia & $66.90 \%$ & $1,912,478$ & 543,382 & 915,925 & 933,170 \\
\hline
\end{tabular}

Source: Calculated from Zong and Batalova (2015).

The Estimated Votes Cast column is (Migrant in Migration - Migrant out Migration) * State Voter Turnout.

Table 2 shows that in one of the ten regions (Vermont), the potential number of Democratic votes received from migrants was slightly greater than the difference in the votes received by the Democratic Presidential candidate in 2012 when compared to 1992. In the other nine regions, the percent of difference explained ranges from $60.09 \%$ in California to $98.15 \%$ in Virginia. The percent of difference explained is calculated as the (Estimated Votes Cast) / (Increase in Democratic Votes).

In Table 3, I provide information on the effect of legal immigration on voting trends in these nine regions. I used data available from the Migration Policy Institute and Demos ${ }^{5}$. I accounted for the number of native-born citizens in each region since 1990, the birthplace of foreign-born immigrants, the estimated voter turnout of each immigrant group, and the number of each immigrant group who were likely to vote for the Democratic presidential candidate.

Since 1976, a majority of new citizen immigrants have voted for the Democrats in every presidential election - except for the 1984 election, when a majority voted for Republican Ronald Reagan. According to Hot Air Magazine (2014):

Immigrants, particularly Hispanics and Asians, have policy preferences when it comes to the size and scope of government that are more closely aligned with progressives than with conservatives. As a result, survey data show a two-to-one party identification with Democrats over Republicans.

\footnotetext{
${ }^{5}$ http://www. demos.org
} 
Table 3. Voting Patterns and Immigration to Selected Regions from 1990 to 2012

\begin{tabular}{|l|c|c|c|c|}
\hline \multicolumn{1}{|c|}{ (a) Region } & $\begin{array}{c}\text { (b) Increase } \\
\text { in Dem. Votes }\end{array}$ & $\begin{array}{c}\text { (c) Migrant } \\
\text { Votes }\end{array}$ & $\begin{array}{c}\text { (d) New } \\
\text { Immigrant } \\
\text { Votes }\end{array}$ & $\begin{array}{c}\text { (e) Percent } \\
\text { Explained }\end{array}$ \\
\hline California & $2,732,960$ & $1,642,330$ & $1,007,013$ & $96.94 \%$ \\
\hline Connecticut & 281,765 & 210,907 & 42,365 & $89.89 \%$ \\
\hline Delaware & 116,530 & 95,410 & 6,815 & $87.72 \%$ \\
\hline $\begin{array}{l}\text { District of } \\
\text { Columbia }\end{array}$ & 74,451 & 43,195 & 9,367 & $70.60 \%$ \\
\hline Hawaii & 127,348 & 100,035 & 20,656 & $94.77 \%$ \\
\hline Maryland & 689,273 & 455,840 & 96,274 & $80.10 \%$ \\
\hline New Jersey & 686,580 & 431,896 & 198,101 & $91.76 \%$ \\
\hline New York & $1,027,421$ & 518,457 & 398,169 & $89.22 \%$ \\
\hline Virginia & 933,170 & 915,925 & 177,459 & $117.17 \%$ \\
\hline
\end{tabular}

Note: Percent Explained is (column c plus column d) divided by column b.

Source: Calculated from Zong and Batalova (2015).

As shown in Table 3, an average of slightly over $90 \%$ of the difference in the number of Democratic votes cast from 1992 to 2012 can be attributed to a combination of voting by interstate migrants and voting by new-immigrant citizens in these nine regions. The Percent Explained column is greater than $100 \%$ in Virginia because much of northern Virginia is part of the Washington D.C. metropolitan area, and residents frequently move between these two regions. Thus, a voter might cast a ballot in Washington D.C. in one election and in Virginia in the next election.

Because I have assumed that the voter turnout percentage of migrants is equal to the voter turnout percentage of the state to which they migrated, the number of migrant votes is probably overestimated in some regions.

\section{Political Dysfunction}

I agree with Dr. Patrick Miller of the University of Kansas, who stated that:

Citizens also carry some burden for the problems that we have in politics today, he said. We very readily condemn all the problems we find in Washington. Yet, we as citizens don't think very often about the role that we have in that. By and large, voters nominate and elect more partisan politicians.

If we're condemning politicians for the way they act in office, they might just be giving us what we as citizens are looking for, that partisan warrior and gridlock. (KU News Service, January 29, 2015, Lawrence, Kansas) 
When polled, voters say that they believe political parties should be more willing to compromise. However, polling results indicate that voters do not believe that Congress should adopt policies that are midway between the positions of the two parties.

DeSilver (2014) has pointed out that:

A majority of consistent conservatives (57\%) say the ideal agreement between President Obama and congressional Republicans is one in which GOP leaders hold out for more of their goals. Consistent liberals take the opposite view: Their preferred terms (favored by $62 \%$ ) end up closer to Obama's position than the GOP's.

In other words, the majority of liberal and conservative voters want Congress to agree with their positions. To these voters, "compromise" means that the political battle ends when the other side surrenders.

In a representative democracy, voters assume that representatives will vote in a manner consistent with the views of their constituents - which is exactly what the members of Congress have been doing over the past sixteen years. It is not reasonable for voters to expect that members of Congress should ignore the wishes of their own constituents in order to adopt compromise legislation.

Political dysfunction in Congress has manifested in three major areas: presidential nominations, budgets, and non-budget legislation. I discuss each of these topics in Sections "Presidential Nominations" through "Non-Budget Legislation" below.

\section{The California Example}

California, ${ }^{6}$ a U.S. state, has eliminated many of the problems of political dysfunction by making changes to its governmental system. Because I believe that some of the changes implemented in California could be productively implemented at the federal level as well, I have included the California example in my discussion below.

\section{Presidential Nominations}

In a typical presidential term, the President will nominate thousands of individuals to fill federal positions (such as marshals, federal department executives, lower court judges, and justices of the U.S. Supreme Court). The U.S. Senate is required to approve or reject each of these nominations by a simple majority vote (U.S. Constitution, Article 2, Section 2). However, the Senate has often delayed hearings on nominations in order to pressure the President to withdraw the nominations, or for other political purposes. Such delays have occurred during both Democratic and Republican administrations.

${ }^{6}$ California has 38.8 million people and a gross state product of $\$ 2.3$ trillion. If California were a country, it would have the world's eighth largest economy as measured by gross domestic product and gross state product. 
In California state government, high-level nominees (officials nominated by the governor) must be confirmed by both the state Assembly and the state Senate. The California constitution requires that high-level gubernatorial nominees must be confirmed or rejected within 90 days of the submission of a nomination (California Constitution, Section 5, Article 5b). If a nominee is not confirmed or rejected, the nominee is allowed to take office without being confirmed (Lower-level nominees take office immediately). If the California legislature rejects a nomination, the person is removed from office and the governor can submit a new nominee.

If the United States Senate were to adopt a similar 90-day rule, it would prevent either party from rejecting a nomination without the vote of the full U.S. Senate. I recommend that such a 90-day rule apply to the appointed head of a cabinet-level department (e.g., Secretary of State) and to U.S. Supreme Court nominees. All other nominees would take office immediately and would remain in office unless they are later rejected by the U.S. Senate.

\section{The Federal Budget}

Political dysfunction has caused 18 U.S. government shutdowns since 1976 (Matthews 2013). However, only eight of these shutdowns have lasted more than seven days. The shutdowns occurred either because Congress could not agree on a budget, or because the President did not agree with the budget passed by Congress.

California had similar problems prior to 2010. From 1991-2010, the California legislature had passed only five $(25 \%)$ of all state budgets under discussion by June 15 as required by the state Constitution. In 2010, California voters passed Proposition 25, which amended the previous requirement that a budget must pass by at least a two-thirds vote. Proposition 25 requires legislators to pass a balanced budget by June 15 of each year by a simple majority vote. If legislators fail to pass a balanced budget by June 15 , they will not be paid until they fulfill that constitutional requirement.

I believe that passage of the federal budget is perhaps the most important yearly requirement of a member of Congress - and that if members of Congress cannot accomplish that primary task, they should not be paid. I recommend that if Congress were to fail to pass a budget by the end of a fiscal year, members of Congress should not be paid until they have fulfilled their primary responsibility. Such a standard would provide representatives with a strong financial incentive to compromise, pass a budget bill, and submit it to the President for signature.

\section{Non-Budget Legislation}

U.S. party leaders and individual Senators have often directly contributed to political dysfunction by preventing votes on legislation that they opposed, especially when such legislation appeared likely to pass both houses of Congress. From 2011-2014, the Democrats were in the majority in the Senate, 
and the Republicans were in the majority in the House. Senate Majority Leader Harry Reid, a Democrat, prevented a vote on many Republican initiatives. These initiatives included budgets passed by the House, and an attempted repeal of the Affordable Care Act. ${ }^{7}$ The Republican Majority Leader (John Boehner) prevented votes on legislation dealing with issues such as immigration reform, minimum wage increase, veterans' benefits, and unemployment-benefit duration increase.

The following factors enabled party leaders to prevent votes on those issues:

1. Senatorial Holds.

2. Senate voting requirements.

3. Hastert Rule.

I discuss each of these factors below.

\section{$\underline{\text { Senatorial Holds }}$}

Daschle and Lott (2013) have recommended that individual senators should not be allowed to place a "hold" on a nominee or a procedural motion. I agree with Daschle and Lott that the Senatorial hold privilege should be eliminated. Senatorial holds are undemocratic, thwart the will of the majority, and prevent voters from knowing how their representative would have voted on important legislation. Worse, a Senatorial hold can be placed anonymously. In that case, no one except the party leader will know who blocked a particular piece of legislation.

I believe that removing the Senatorial privilege of placing a hold on nominees would reduce political dysfunction.

\section{$\underline{\text { Senate Voting Requirements }}$}

The U.S. Senate Rules require that every bill receive a three-fifths super majority before debate can be abbreviated and a bill voted on. This supermajority requirement should be eliminated, and a simple majority of senators should be allowed to determine whether debate on a bill should be abbreviated. The super-majority requirement is undemocratic, thwarts the will of the majority, and prevents voters from knowing how their representative would have voted on important legislation.

\section{$\underline{\text { Hastert Rule }}$}

Dennis Hastert was the Republican Speaker of the U.S. House of Representatives from 1999 to 2007. He is best known for popularizing the "Hastert Rule" in 1999. Under this doctrine, the Speaker of the United States

\footnotetext{
${ }^{7}$ The Affordable Care Act is often referred to as "Obamacare".
} 
House of Representatives will not allow a floor vote on a bill unless a majority of the majority-party representatives supports the bill.

Under the Hastert Rule, a party caucus considers major bills and effectively decides whether they will be voted on. This is similar to a pre-vote on the bill.

The House and Senate Rules could be changed to give more power to the minority leaders, thereby reducing political dysfunction. I recommend that the House and Senate minority leaders be allowed to move up to ten bills per twoyear session of Congress to a floor vote on a no-amendment basis. This voting reform would significantly decrease political dysfunction and empower minority party members with an incentive to work with the majority party to pass legislation. Because the minority party has almost no affect on legislation, their only viable political alternative is to oppose every idea proposed by the majority party. This is, of course, the essence of political dysfunction.

\section{Conclusion}

I showed that dysfunctional government in the U.S. is largely a byproduct of "political segregation": a phenomenon in which liberals tend to relocate to live in areas where liberal voters are in the majority, and conservatives tend to relocate to live in areas where conservative voters are in the majority.

I analyzed U.S. presidential election data by state from 1976-2012, and showed that a shift occurred in voting behavior for key American states. I believe that this political shift began to occur after 1976, and I explored some of the reasons for these political trends. I reviewed and discussed the psychological literature related to voting behavior.

I hypothesized that individual U.S. federal legislators are following the wishes of the vast majority of voters in their districts, and that dysfunctional government is a byproduct of political segregation, not simply a function of the intransigence of individual legislators.

I found that political dysfunction is caused by interstate migration of voters between conservative and liberal states, and by the magnitude of immigration into liberal states. I recommended that political dysfunction be reduced by eliminating Senatorial holds, by eliminating super majority voting rules, and by allowing minority leaders to bring up to ten bills per session to a floor vote in the House and Senate. Finally, using the example of the California State Legislature, I recommended various rule changes that might reduce political dysfunction at the U.S. federal level.

\section{Acknowledgments}

Thanks to Dr. Katarzyna Romanczyk and Susan H. Kruse (M.S., PMHLP) for their helpful comments and suggestions, to Gina L. Serman Reid (B.S.), manuscript editor, and to W. Samuel Ashley (A.S.), research assistant. 


\section{References}

Bishop B, Cushing R (2008) The Big Sort: Why the Clustering of Like-Minded America is Tearing Us Apart. USA: Houghton Mifflin Company.

Bowling C, Pickerill J (2013) Fragmented federalism: The state of American federalism 2012-13. Publius: The Journal of Federalism 43(3): 315-46.

Constitution of the State of California (1879) compiled by Paul Mason. California State Printing Office (1933) Sacramento, California.

Cooperative Congressional Election Study (2015) Retrieved from http://bit.ly/ 1Snwqy0.

Daschle T, Lott T (2013, November 30) How to Reduce Dysfunction in Congress. The Cap Times. Retrieved from http://bit.ly/1lJd9g2.

DeSilver D (2014, June 12) The polarized Congress of today has its roots in the 1970s. Pew Research Center. Retrieved from http://pewrsr.ch/115eCuB.

Hogg M, Zachary P, Rivera J (2008) Why Do People Join Groups? Three Motivational Accounts from Social Psychology. Social and Personality Psychology Compass 2: 1269-1280. doi: 10.1111/j.1751-9004.2008.00099.

Hot Air Magazine (2014, April 15) Study: Yes, more immigration means more Democratic votes. Retrieved from http://bit.ly/1Hmc8Es.

KU News Service (2015, January 29) Study: blame Men for political gridlock; Women may be better at compromise. Lawrence, Kansas.

Lupu N (2015) Party Polarization and Mass Partisanship: A Comparative Perspective. Political Behavior 37: 331-356.

Mann T, Carrado A (2014) Party Polarization and Campaign Finance. Strengthening American Democracy 96. Brookings Institution. Retrieved from http://brook.gs/ $1 \mathrm{XqeYu} 4$.

Migration Policy Institute U.S. Immigrant Population by State and County. Retrieved from http://bit.ly/1PYutsA.

Ortoleva P, Snowberg E (2015) Overconfidence in Political Behavior. American Economic Review 105(2):504-535.

Pickerill J, Bowling C (2014) Polarized Parties, Politics, and Policies: Fragmented Federalism in 2013-2014. Publius: The Journal of Federalism 44(3): 369-398.

Poole K (2012) Graphic picture of a polarized congress. UGA Research 41(1): 32-33.

Sunstein C (1999) The Law of Group Polarization. John M. Olin Working Paper No. 91 (2D series), University of Chicago Law School. Retrieved from from the Chicago Working Paper Series Index: http://bit.ly/1N7sA7Q and The Social Science Research Network Electronic Paper Collection: http://bit.ly/1QHA5Jo.

Matthews D (2013, September 25) Here is every previous government shutdown, why they happened and how they ended. The Washington Post. Retrieved from http:// wapo.st/11JhaBc.

Zong J, Batalova J (2015) Frequently Requested Statistics on Immigrants and Immigration in the United State. Migration Policy Institute. Retrieved from http:// bit.ly/1N9QQWK. 
